\title{
HUBUNGAN RATING BINTANG TERHADAP PERAN AKUNTANSI MANAJEMEN STRATEGIS (Studi Empiris Pada Perusahaan Hotel di Sumatera Selatan)
}

\author{
Antonius Singgih Setiawan ${ }^{1}$ \\ Fakultas Bisnis \& Akuntansi Universitas Katolik Musi Charitas \\ assetiawan1208@gmail.com \\ Rahmawati \\ Fakultas Ekonomi Bisnis Universitas Sebelas Maret
}

\begin{abstract}
This study aims to test whether the star rating as parameter of level hotel to bring a better impact on the implementation of strategic management accounting role in the management of the hotel business. Using a sample of 66 respondents General Manager/Leader of Hotel in the province of South Sumatra (resepon rate 88\%), research hypotheses were tested using regression analysis. The results showed that the star rating hotel a positive impact on the implementation of strategic management accounting role in functional role of accounting and the use of strategic management accounting techniques.
\end{abstract}

Keywords: Hotel, Star Rating, Functional Role of Accounting, Strategic Management Accounting Techniques Use

Abstrak: Penelitian ini bertujuan menguji apakah rating bintang sebagai parameter level perusahaan hotel membawa dampak yang lebih baik terhadap implementasi peran akuntansi manajemen strategis dalam pengelolaan bisnis hotel. Menggunakan 66sampel responden General Manager/Pimpinan Hotel di wilayah Provinsi Sumatera Selatan (resepon rate $88 \%$ ), hipotesis penelitian diuji menggunakan analisis regresi. Hasil penelitian menunjukkan bahwa rating bintang hotel memberikan dampak positif terhadap implementasi peran akuntansi manajemen strategis baik peran fungsional akuntansi maupun penggunaan teknik akuntansi manajemen strategis.

Kata kunci: Hotel, Rating Bintang, Peran Fungsional Akuntansi, Penggunaan Teknik Akuntansi Manajemen Strategik

\section{PENDAHULUAN}

Akuntansi telah menjadi faktor kunci dalam aktifitas bisnis dunia. Akuntansi telah berkembang dalam peran, praktik dan teknologi. Akuntansi tidak lagi hanya sebagai aktifitas teknis namun sudah menjadi aktifitas strategis. Hal ini menunjukkan bahwa peran akuntansi telah bergeser dari peran tradisional ke peran yang lebih modern. Pergeseran peran ini terjadi karena akuntansi harus merespon perubahan ekonomi bisnis secara global (Colomen, 1949). Evolusi peran akuntansi ini pada akhirnya berdampak pada perkembangan literasi yang saat ini sering kita kenal dengan akuntansi manajemen strategik.

Akuntansi manajemen strategik pada awalnya diperkenalkan oleh Simmonds (Nixon dan Burns (2012). Brouthers dan Roozen (1999) menunjukkan bahwa fungsi strategis dari

${ }^{1}$ Saat ini sedang menempuh studi S3 pada PDIE UNS 
sistem akuntasi strategisadalah sebagai alat analisis lingkungan, generasi alternatif strategis, pemilihan alternatif strategis, perencanaan pelaksanaan strategis, implementasi rencana strategis serta sebagai proses pengendalian manajemen strategis. Untuk mencapai implementasi tersebut maka dibutuhkan peran dari fungsional akuntansi yaitu peran personil akuntansi serta penggunaan alat-alat atau teknologi akuntansi manajemen yang memadai. Dua hal tersebut merupakan faktor integral dalam implementasi peran akuntansi manajemen strategik.

Praktik dan peran akuntansi manajemen strategik telah masuk keberbagi jenis industri, baik itu industri manufaktur, dagang maupun jasa. Hal ini tercermin dari berbagai hasil penelitian yang antara lain telah dilakukan oleh Hoque (2004), Hynoven (2007), Flemming (2009), Lee \& Yang (2011), Bastian \& Muchlish (2012), Teeratansirikool,et al (2013), Cadez \& Guilding (2008), Manciati \& Pessina (2014), yang meneliti tentang berbagai faktor dimensi strategi yang memengaruhi parktik dan implementasi akuntansi manajemen strategik pada suatu perusahaan. Pada sisi yang lain beberapa penelitian seperti yang telah dilakukan oleh Cadez dan Guilding (2008), Bisbe dan Malagueno (2012), Macinati dan Pessina (2014), Cleary (2015) telah melihat bahwa praktik dan implementasi akuntansi manajemen strategik dapat berdampak pada kinerja perusahaan, baik kinerja keuangan maupun kinerja non keuangan.

Berdasarkan dua kelompok penelitian tersebut dapat dilihat bahwa peran akuntansi manajemen strategik dapat dilihat berdasarkan sebab dan akibat. Faktor strategi dapat menjadi penyebab peran akuntansi manajemen strategik berkembang. Pilihan strategi, formulasi strategi serta orientasi pasar dianggap faktor yang dapat menyebabkan peningkatan peran akuntansi manajemen strategik. Sementara saat peran akuntansi manajemen strategik meningkat maka akan berakibat pada kinerja perusahaan yang semakin baik. Namun peningkatan peran akuntansi manajemen strategik dalam sebuat perusahaan dapat dimungkinkan karena karateristik level perusahaan yang mungkin berbedaLamminmaki (2008). Sementara level perusahaan yang mudah dilihat oleh masyarakat umum adalah level bintang yang ada pada industri perhotelan.

Atas dasar tersebut, menjadi menarik jika penelitian ini diarahkan pada upaya untuk melihat hubungan antara faktor level perusahaan terhadap peran akuntansi manajemen strategik dalam pengelolaan bisnis. Hal ini seperti diungkapkan oleh Lamminmaki (2008) bahwa hotel yang memiliki kualitas lebih tinggi akan memiliki sistem manajemen yang lebih canggih. Dan kualitas hotel akan tercermin dari level atau rating bintang yang dimilikinya. Terdapat alasan kuat mengapa penelitian akuntansi manajemen relevan dilakukan pada industri jasa perhotelan. Collier dan Gregory (1995) memberikan alasan bahwa saatini fungsi keuangan pada industri hotel menjadi semakin terlibat dalam akuntansi manajemen strategik, baik dalam perencanaan dan dalam menilai kondisi pasar maupun melakukan analisis pesaing.

Tari et al. (2009) menjelaskan bahwa hotel yang memiliki level sertifikasi yang baik akan memiliki teknologi informasi yang lebih memadai untuk mendukung penciptaan kinerja. Hal yang sama diungkapkan oleh Claver et al. (2006) bahwa kualifikasi sertifikasi hotel akan berdampak pada implementasi pengelolaan yang berdampak positif terhadap kinerja. Hal ini semakin menguatkan kemungkinan bahwa semakin tinggi level perusahaan maka akan berdampak pada semakin tingginyaketerlibatan fungsi strategis dalam perusahaan dan semakin tingginya penggunaan teknologi canggih guna mendukung penciptaan kinerja yang optimal, dan hal ini tidak terkecuali bagi industri jasa perhotelan.Oleh karena itu, penelitian ini akan melihat bagaimana level perusahaan dalam 
konteks rating bintang hotel berpengaruh terhadap peran akuntansi manajemen strategik dalam pengelolaan bisnis hotel.

Penelitian ini akan difokuskan pada perusahaan perhotelan di wilayah Sumatera Selatan.Pemilihan perusahaan perhotelan di wilayah Sumatera Selatan sebagai subjek penelitian bukan tanpa alasan. Jika melihat perkembangan industri perhotelan di wilayah Sumatera Selatan, industri hotel telah berkembang sangat pesat baik secara jumlah maupun sifat dan kualitas layanannya, terutama hotel yang berklasifikasi bintang. Hal ini dipengaruhi oleh semakin banyaknya even yang diselenggarakan di Provinsi Sumatera Selatan khususnya kota Palembang. Pertumbuhan yang pesat dari industri perhotelan di Sumatera Selatan secara langsung akan berdampak pada tingkat persaingan hotel yang semakin ketat, sehingga peran fungsi-fungsi strategis akan sangat diperlukan tidak terkecuali adalah fungsi akuntansi.

Berdasarkan situasi terkini tersebut, menimbulkan sebuah peluang penelitian yang dapat dilakukan untuk melihat apakah terdapat hubungan antara level hotel dalam konteks rating bintangterkait dengan peran akuntansi manajemen strategikuntuk kasus di Indonesia, khususnya pada industri perhotelan di Sumatera Selatan. Oleh karena itu, pertanyaan penelitian yang akan dijawab dalam penelitian ini adalah apakah rating bintang hotel akan berdampak pada peningkatan peran akuntansi manajemen strategik baik dalam konteks peran fungsional akuntansi maupun penggunaan teknik-teknik akuntansi manajemen strategik di industri hotel di wilayah Sumatera Selatan.

\section{KAJIAN TEORI}

Untuk memahami konsep akuntansi strategik, Cadez dan Guilding (2008) menggambarkan dua perspektif mendasar dari akuntansi manajemen startegik, yaitu orientasi pada teknik-teknik akuntansi strategis dan, keterlibatan fungsional akuntansi, dalam hal ini adalah akuntan di perusahaan dalam proses pengambilan keputusan strategis perusahaan. Implementasi akuntansi manajemen strategik dapat tercermin pada pemanfaatan teknologi akuntansi canggih(Gil, 2004), penggunaan sistem kinerja terintegrasi (Brouthers dan Roozen,1999)yang pada akhirnya dapat secara optimal membantu memberikan informasi penting, relevan dan realibel dalampembuatan keputusan dan pengendalian strategis (Bromwich 1996).

Guilding et al. (2000) menjelaskan bahwa untuk mencapai implementasi peran akuntansi manajemen strategik dalam sebuah kegiatan bisnis, tiga karateristik kerangka klasifikasi komprehensif teknik akuntansi manajemen strategik harus terpenuhi. Tiga karateristik tersebut adalah berorientasi pada lingkungan atau pemasaran, berfokus pada pesaing, dan memiliki orientasi jangka jangka panjang.Berdasarkan uraian mengenai konsep akuntansi manajemen strategik tersebut, jelas bahwa tidak sembarang perusahaan mampu mengiplementasikan konsep tersebut. Dibutuhkan kualifikasi tertentu bagi perusahaan untuk mampu mengimplementasikannya. Perusahaan dengan skala level modern dan berkulitas yang mampu mengimplementasikan hal tersebut. Pada industri hotel, level rating bintang menjadi parameter kualifikasi yang mungkin dapat menjelaskan bagaimana implementasi akuntansi manajemen strategik dilakukan.Hal tersebut didukung oleh Rhee dan Yang (2015) menyatakan bahwa kelompok hotel berklasifikasi bintang tinggi cenderung lebih besar mengejar valuedari pada kelompok hotel berklasifikasi bintang yang lebih rendah, dan sistem rating bintang menandakan bahwa hotel secara 
independen bermerek sehubungan dengan kualitas yang mereka miliki (Lamminmaki, 2008)

Lamminmaki (2008) menemukan bahwa kualitas hotel yang didasarkan pada rating bintang berpengaruh positif terhadap peran kecangihan akuntansi pada industri perhotelan di Australia. Pada sisi lain Tari et al. (2009) menyimpulkan bahwa kualitas hotel yang ditunjukan dengan bersertifikasi memiliki kinerja yang lebih baik dari pada hotel yang tidak bersertifikasi.Kim et al. (2013) menyimpulkan bahwa tipe hotel berpengaruh pada hubungan antara operasi atau strategi hotel, hal ini dapat diartikan bahwa operasi hotel juga berhubungan dengan peran fungsional yang ada di organisasi hotel termasuk didalamnya adalah fungsional akuntansi, serta strategi hotel dalam memanfaatkan alat-alat akuntansi canggih guna mendukung pengumpulan informasi sebagai dasar pengambilan keputusan strategis. Berdasarkan uraian di atas nampak bahwa kualitas menjadi kunci penting dalam mengiplementasikan akuntansi manajemen strategik bagi perusahaan, oleh karena itu hipotesis yang akan dibuktikan dalam penelitian ini adalah;

H1 : Semakin tinggi rating bintang sebuah hotel akan berdampak positif terhadap peran fungsional akuntansi dalam pengelolaan bisnis hotel

H2 : Semakin tinggi rating bintang sebuah hotel akan berdampak positif terhadap penggunaan teknik akuntansi manajemen strategik dalam pengelolaan bisnis hotel

\section{METODE}

Populasi dan Sampel. Penelitian ini bertujuan untuk menguji rating bintang sebagai indikator level perusahaan perhotelan dapat mempengaruhi peran akuntansi manajemen strategis di industri perhotelan berbintang di Sumatera Selatan. Perusahaan perhotelan berbintang dipilih karenapertumbuhan industri perhotelan di wilayah Sumatera Selatan saat ini begitu pesat. Hal ini memicu persaingan yang kuat, sehingga perlu dikaji apakah perbedaan level perusahaan dalam rating bintang berdampak pada implementasi peran akuntansi manajemen strategik dalam pengelolaan hotel di Sumatera Selatan. Berdasarkan permasalahan tersebut, maka populasi objek penelitian yang relevan dalam penelitian ini adalah para manajemen perusahaan perhotelan di wilayah Sumatera Selatan.Sampel dalam penelitian ini adalah manajemen perusahaan (General Manager/Pimpinan)hotel berbintang di wilayah Sumatera Selatan yang terlibat dan bertanggung jawab dalam pengelolaan hotel, dan memiliki informasi mengenai permasalahan yang akan diteliti.

Variabel dan Pengukuran Variabel. Variabel penelitian ini terdiri dari variabel dependen Peran Akuntansi Manajemen Strategik yang terdiri dari dua dimensi yaitu (1) Peran Fungsional Akuntansi dan (2) Penggunaan Teknik Akuntansi Manajemen Strategik, variabel independen Rating Bintang Hotel. Pengukuran variabel dapat dijelaskan sebagai berikut: (1) Peran Akuntansi Manajemen Strategik, (a). Peran Fungsional Akuntansi (akuntan/tim akuntansi) adalah peran aktif akuntan/tim akuntansi dalam berkontribusi menghasilkan keputusan strategis perusahaan. Pengukuran partisispasi akuntan/tim akuntansi menggunakan instrumen yang dipakai Cadez dan Guilding (2008) yang diadopsi dari Wooldrige dan Floyd's (1990). Responden diminta untuk merekam partisipasi akuntan terkait dengan lima aspek manajemen strategis, (i) mengidentifikasi masalah dan mengusulkan tujuan, (ii) menghasilkan pilihan, (iii) mengevaluasi pilihan, (iv) mengembangkan secara detail setiap pilihan, (v) mengambil tindakan yang diperlukan untuk perubahan perusahaan. Jawaban menggunakan skala 6 point $(1=$ tidak sama sekala 
berperan, 6 = berperan secara penuh).(b).Penggunaan Teknik Akuntansi Manajemen Strategik adalah penggunan teknik-teknik akuntansi manajemen canggih dalam mendukung kegiatan operasi perusahaan. Penggunaan sistem akuntansi manajemen strategis menggunakan 11 instrumen yang dipakai Cinquini dan Tenucci (2008) yang diadopsi dari Cadez dan Guilding (2006); Cravens dan Guilding (2001); serta Guilding dan McManus (2002). Jawaban menggunakan skala 6 point $(1=$ tidak pernah sama sekali digunakan, 6 = selalu digunakan). Berikut adalah 11 teknik akuntansi manajemen strategik; activity based costing/management, life cycle costing, quality costing, target costing, value chain costing, coustomer accounting, competitive position monitoring, competitor cost assesment, competitor performance appraisal, benchmarking, integrated performance measurement.(2).Rating Bintangadalah level perusahaan atau level kualitas hotel yang dilihat berdasarkan tingkat bintang hotel. Pengukuran rating bintang menggunakan instrumen Lamminmaki (2008) dengan skala 1 adalah hotel bintang 1 sampai 5 adalah hotel bintang 5 .

Analisis Data Penelitian. Statistik deskriptif untuk memberikan gambaran mengenai demografi responden yang meliputi umur, tingkat pendidikan, pengalaman kerja, jenis kelamin, dan deskripsi mengenai variabel-variabel penelitian. Penelitian ini menggunakan total deskriptif absolut yang menunjukan angka maksimum, minimum, rata-rata, median dan standar deviasi.

Uji Reliabilitas dan Validitas. Pengujian dengan melihat nilai Cronbach Alpha lebih besar dari 0,7 (Ghozali, 2013). Pengujian validitas dapat dilakukan dengan melhat Corrected Item-Total Correlation dengan kriteria sebagai berikut: jika $\mathrm{r}$ hitung $>\mathrm{r}$ tabel, maka pernyataan tersebut dapat dikatakan "valid", namun jika nilai $r$ hitung $<\mathrm{r}$ tabel, maka pernyataan tersebut dapat dikatakan "tidak valid". Uji Reliabilitas dan validitas dipakai untuk melihat instrumen variabel Peran Fungsional Akuntansi dan Penggunaan Teknik Akuntansi Manajemen Strategik.

Uji Normalitas. Untuk menguji normalitas model regresi. Uji normalitas menggunakan uji statistik Kolmogorov-Smirnov dengan kriteria jika $p$-value $<0,05$ maka hipoteisi nol akan ditolak yang berarti data tidak terdistribusi secara normal dan hal ini menyalahi asumsi, sedangkan yang diharapkan adalah p-value > 0.05 sehingga data terdistribusi secara normal. (Ghozali, 2013).

Uji Hipotesis. Hipotesis diuji menggunakan uji statistik regresi dengan tingkat penerimaan hipotesis 5\%. Yang terdiri dari dua model penelitian dimana Model I untuk menguji H1 dan Model II untuk menguji H2, berikut adalah persamaan model penelitian:

$$
\begin{array}{ll}
\text { Model I } & : \text { PFA }=a+b \mathrm{RB}+e \quad \ldots \ldots \ldots \ldots . . . \mathrm{H}_{1} \\
\text { Model II } & : \text { PAMS }=a+b \mathrm{RB}+e \ldots \ldots \ldots \ldots . . . \mathrm{H}_{2}
\end{array}
$$

Keerangan: PFA : Peran Fungsional Akuntansi; PAMS : Penggunaan Akuntansi Manajemen Strategik; RB : Rating Bintang; $a$ : Konstanta; $b$ : Koefisien regresi; $e$ : Residual

\section{HASIL DAN PEMBAHASAN}

Data penelitian dikumpulkan menggunakan koesioner. Survei dilakukan terhadap 75 hotel berbintang meliputi bintang 1 sampai bintang 5 diwilayah Sumatera Selatan, yang 
terdaftar di berbagi situs booking hotel seperti www.agoda.com,www.traveloka.com dan www.hotelcombined.com. Dari 75 hotel yang tersurvei, 9 hotel gagal tersurvei berbagai alasan. 66(88\%) hotel lainnya berhasil tersurvei dan memberikan data yang lengkap sesuai dengan kebutuhan penelitian. Maka berdasarkan 66 koesioner tersebut penelitian ini dilakukan.

Tabel 1 menunjukkan profil responden yang berpartisipasi dalam penelitian ini. Responden yang terlibat dalam penelitian ini berjumlah 66 orang. Dilihat dari sisi gender, pimpinan yang terlibat sebagai responden dalam penelitian adalah laki-laki sebanyak 46 orang $(69,7 \%)$, sementara responden perempuan sebanyak 20 orang $(30,3 \%)$ orang. Hal ini menunjukkan peran laki-laki masih dominan dalam pengelolaan dan pengambilan keputusan sebuah organisasi bisnis terutama bisnis perhotelan di wilayah Sumatera Selatan. Profil responden dalam tingkat pendidikan tertinggi, Pendidikan S1 mendominasi tingkat pendidikan terakhir dari responden sebanyak 38 orang (57,6\%). Tingkat pendidikan Diploma sebanyak 24 orang $(36,4 \%)$, sisanya tingkat pendidikan S2 sebanyak 2 orang (3\%) dan lainya (SLTA) sebayak 2 orang (3\%). Profil responden berdasarkan usia, dapat dilihat bahwa rata-rata usia responden adalah 38,38 tahun dengan usia termuda 22 tahun sementara usia tertua 66 tahun. Hal ini menunjukkan bahwa rata-rata usia pempinan hotel berada pada tingkat usia yang produktif, sehingga hal ini menunjukkan bahwa regenerasi pempinan industri hotel dipandang menjadi penting untuk menghadapai tingginya persaingan yang terjadi saat ini. Dan jika dilihat dari lamanya menjabat, rata-rata responden yang terlibat dalam pengelolaan hotel telah menjabat selam 5,39 tahun. Dimana masa menjabat terbaru adalah 1 tahun sementara masa terlama adalah 31 tahun. Informasi ini menunjukkan bahwa, dengan rata-rata responden telah terlibat pengelolaan hotel selama 5,39 tahun dapat dinyakini reponden telah memahami betul situasi yang ada di hotel yang mereka kelola, sehingga dapat memberikan informasi yang relevan untuk penelitian ini.

Tabel 1. Data Demografi Responden

\begin{tabular}{lccc}
\hline \multicolumn{1}{c}{ Profil Responden } & Jumlah & $(\%)$ & \\
\hline 1. Jenis Kelamin & & & \\
a. Perempuan & 20 & 30,3 & \\
b. Laki-laki & 46 & 69,7 & \\
2. Pendidikan Terakhir & & & \\
a. Diploma & 24 & 36,4 & \\
b. S1 & 38 & 57,6 & \\
c. S2 & 2 & 3,0 & Rata-rata \\
d. S3 & 0 & 0 & 38,38 \\
e. Lainnya & 2 & 3,0 & 5,39 \\
\cline { 2 - 4 } & Termuda/terbaru & Tertua/terlama & 66 \\
3. Usia & 22 & 31 & \\
4. Lama Menjabat & 1 & &
\end{tabular}

Sumber: Data diolah

Tabel 2 menunjukkan statistik data penelitian. Profil level perusahaan yang ditunjukkan dari kualifikasi rating bintang, hotel dengan kualifikasi bintang 2 berjumlah lebih banyak yaitu 24 hotel $(36,4 \%)$, kualifikasi bintang 3 sebanyak 22 hotel $(33,3 \%)$, terbanyak ketiga adalah kualifikasi hotel bintang 1 sebanyak 10 hotel $(15,2 \%)$, sementara hotel berkualifikasi bintang 4 sebanyak 8 hotel $(12,1 \%)$, sedangkan hotel berkualifikasi bintang 5 terdapat 2 hotel (3\%). Data ini menunjukkan bahwa, mayoritas investor lebih 
memilih untuk menjalankan bisnis hotel diwilayah Sumbagsel pada kualifikasi bintang menengah kebawah yaitu cenderung ke bintang 3, bintang 2 dan bintang 1 .

Tabel 2 juga menunjukkan data Peran Fungsional Akuntansi dalam kegiatan pengelolaan hotel di Sumatera Selatan menunjukkan angka rata-rata 22,82. Berdasarkan kisaran teoritsi antara 5 sampai dengan 30, oleh karena itu dapat disimpulkan bahwa Peran Fungsional Akuntansi dalam kegiatan pengelolaan hotel di wilayah Sumatera Selatan dapat digolongkan dalam tingkatan yang relatif tinggi. Begitu pula untuk tingkat Penggunaan Akuntansi Manajemen Strategik, berdasarkan kisaran teoritis antara 11 sampai dengan 66, rata-rata Penggunaan Teknik Akuntansi Manajemen Strategik yang dilakukan oleh perusahaan hotel di wilayah Sumatera Selatan berada pada angka 50,67. Hal ini dapat disimpulkan bahwa tingkat Penggunaan Akuntansi Manajemen Strategik pada perusahaan Hotel di wilayah Sumatera Selatan adalah tinggi.

Tabel 2. Statistik Data Penelitian

\begin{tabular}{lcccc}
\hline \multicolumn{1}{c}{ Variabel Penelitian } & Jumlah & $(\%)$ & & \\
\hline Rating Bintang & & & & \\
Bintang 1 & 10 & 15,2 & & \\
Bintang 2 & 24 & 36,4 & & \\
Bintang 3 & 22 & 33,3 & & \\
Bintang 4 & 8 & 12,1 & & \\
Bintang 5 & 2 & 3,0 & & \\
& & & & \\
\cline { 2 - 5 } & Kisaran & Kisaran & \multirow{2}{*}{ Mean } & Standar \\
& Teoritis & aktual & & Deviasi \\
\cline { 2 - 5 } & $5-30$ & $10-30$ & 22,82 & 5,54 \\
Peran Fungsional Akuntansi & $11-66$ & $22-66$ & 50,67 & 10,05 \\
Penggunaan Akuntansi Manajemen & & & & \\
Strategik & & & & \\
\hline
\end{tabular}

Sumber: Data diolah

Tabel 3. Uji Validitas

\begin{tabular}{lccc}
\hline \multicolumn{1}{c}{ Variabel Penelitian } & r hitung & r tabel & Kesimpulan \\
\hline Peran Fungsional Akuntansi & & & \\
PFA 1 & 0,916 & 0,242 & Valid \\
PFA 2 & 0,964 & 0,242 & Valid \\
PFA 3 & 0,916 & 0,242 & Valid \\
PFA 4 & 0,959 & 0,242 & Valid \\
PFA 5 & 0,919 & 0,242 & Valid \\
\hline Penggunaan Akuntansi Manajemen Strategik & & \\
ABC & 0,638 & 0,242 & Valid \\
LCC & 0,620 & 0,242 & Valid \\
QC & 0,807 & 0,242 & Valid \\
TC & 0,832 & 0,242 & Valid \\
VCC & 0,877 & 0,242 & Valid \\
CA & 0,637 & 0,242 & Valid \\
CPM & 0,864 & 0,242 & Valid \\
CCA & 0,782 & 0,242 & Valid \\
CPA & 0,805 & 0,242 & Valid \\
BM & 0,802 & 0,242 & Valid \\
IPM & 0,800 & 0,242 & Valid \\
\hline
\end{tabular}

Sumber: Data diolah 
Tabel 3 menunjukkan hasil pengujian validitas data penelitian. Uji validitas didasarkan nilai corrected item total correlation (nilai $r$ hitung). Berdasarkan jumlah sampel 66, maka kreteria nilai $r$ kritis adalah berada pada degree of freedom $n$ : $66-2=$ 64 , pada $\alpha 5 \%$ two tail yang menunjukkan angka 0,242 . Oleh karena itu, semua indikator variabel Peran Fungsional Akuntansi dan Penggunaan Akuntansi Manajemen Strategik dinyatakan valid. Hal ini dibuktikan bahwa semua nilai $r$ hitung dari setiap indikator variabel memiliki angka lebih besar dari nilai $r$ tabel 0,242.

Tabel 4. Uji Reliabilitas

\begin{tabular}{lccc}
\hline \multicolumn{1}{c}{ Variabel Penelitian } & $\begin{array}{c}\text { Crombach } \\
\text { Alpha }\end{array}$ & $\begin{array}{c}\text { Nilai } \\
\text { Kritis }\end{array}$ & Kesimpulan \\
\hline Peran Fungsional Akuntansi & 0,978 & 0,7 & Reliabel \\
Penggunaan Akuntansi Manajemen Strategis & 0,946 & 0,7 & Reliabel \\
\hline
\end{tabular}

Sumber: Data diolah

Tabel 4 menunjukkan hasil pengujian reliabilitas data penelitian. Reliabilitas data didasarkan pada nilai crombach alpha dari setiap data variabel penelitian. Hasil pengujian crombach alpha menunjukkan bahwa semua variabel yang diuji, meliputi variabel Peran Fungsional Akuntansi dan Penggunaan Akuntansi Manajemen Strategik menunjukkan angka diatas nilai kritis yang disyaratkan $(0,6)$. Oleh karena itu dapat disimpulkan bahwa, semua data variabel yang diuji menunjukkan hasil yang realibel, sehingga data layak dipakai untuk proses penelitian selanjutnya.

Tabel 5. Uji Normalitas Model Regresi

\begin{tabular}{cccc}
\hline Model & Nilai K-S & Asym.Sig & Keimpulan \\
\hline$P F A=a+b R B+e$ & 0,685 & 0,736 & Normal \\
$P A M S=a+b R B+e$ & 0,533 & 0,938 & Normal \\
\hline
\end{tabular}

Sumber: Data diolah

Berdasarkan tabel. 5 dapat dilihat hasil pengujian normalitas model penelitian Iadalah normal dengan ditunjukan nilai signifikansi KS 0,736 $\geq 0,05$. Begitupun untuk model penelitian II juga normal dengan ditunjukan nilai signifikansi KS 0,936 $\geq 0,05$.

Tabel 6. Pengujian Regresi

\begin{tabular}{lccr}
\hline & Koefisien & p-value & Keputusan \\
\hline Model I : $P F A=a+b R B+e$ & & & \\
Konstanta & 18,365 & & \\
Rating Bintang & 1,771 & 0,009 & H1 didukung \\
Variabel dependen: Peran Fungsional Akuntansi & & \\
Model II : $P A M S=a+b R B+e$ & 38,602 & & \\
Konstanta & 4,797 & 0,000 & H2 didukung \\
Rating Bintang & &
\end{tabular}

Berdasarkan Tabel 6 dapat dilihat bahwa Model I merupakan model regresi yang menjelaskan rating bintang hotel dapat berpengaruh positif terhadap peran fungsional 
akuntansi dalam pengelolaan bisnis hotel. Berdasarkan hasil pengujian regresi pada tabel 6. koefisien regresi rating bintang terhadap peran fungsional akuntansi sebesar 1,771 dengan nilai signifikansi $0,009<\alpha 5 \%$. Nilai koefisien regresi rating bintang menunjukkan makna bahwa semakin tinggi rating bintang sebuah hotel maka akan berdampak pada semakin tingginya peran fungsional akuntansi pada perusahaan hotel di Sumatera Selatan.

Model II juga menunjukkan rating bintang hotel dapat berpengaruh positif terhadap penggunaan akuntansi manajemen strategik dalam pengelolaan bisnis hotel. Koefisien regresi rating bintang terhadap penggunaan akuntansi manajemen strategik sebesar 4,797 dengan nilai signifikansi $0,000<\alpha 5 \%$. Nilai koefisien regresi rating bintang menunjukkan makna bahwa semakin tinggi rating bintang sebuah hotel maka akan berdampak pada semakin tingginya penggunaan akuntansi manajemen strategik pada perusahaan hotel di Sumatera Selatan. Dengan demikian hasil penelitian ini mendukung hipotesis penelitian yang menyatakan rating bintang berpengaruh positif terhadap peran fungsional akuntansi dan penggunaan teknik akuntansi manajemen strategik dalam pengelolaan bisnis hotel.

Hasil pengujian hipotesis telah membuktikan bahwa semua hipotesis terdukung. Temuan ini mendukung temuan penelitian sebelumnya yang dilakukan oleh Lamminmaki (2008); Tari et al. (2009); Kim et al. (2013) yang pada dasarnya adalah setiap hotel yang memiliki kualifikasi sertifikasi yang lebih baik akan memiliki sistem pengelolaan hotel yang lebih canggih dan pada akhirnya akan berdampak pada pencapaian kinerja yang lebih baik pula. Temuan ini juga terkonfirmasi dari hasil wawancara yang dilakukan terhadap Chief AccountingHotel Bintang 5 yang menyatakan:

..... semakin tinggi level bintang implementasi fungsional dan teknologi akuntansi semakin baik...... ${ }^{2}$

Hal ini didukung oleh pernyataan seorang Financial Controller Hotel Bintang 4 jaringan internasional yang menyatakan;

......Semakin tinggi bintang maka fungsi akuntansi dan teknologi yang dipakai akan semakin canggih, karena berkaitan dengan fasilitas yang diberikan ...... kinerja hotel bintang 1 dengan bintang 5 berbeda karena fasilitas berbeda sehingga target cost dan target revenue juga berbeda ..... kinerja hotel mencerminkan target yang ekuivalen dengan kualitas ..... ${ }^{3}$

Hal sama dijelaskan oleh seorang General Manager Hotel Bintang 3 jaringan nasional, yang menyatakan;

..... semakin tinggi rating bintang maka akan semakin canggih fungsi akuntansi yang diimplementasikan baik personalia maupun alat, karena semakin banyak fasilitas yang dikelola....... ${ }^{4}$

Tiga pernyataan dari praktisi hotel tersebut menguatkan dukungan terhadap temuan empiris dari penelitian ini. Kompleksitas hotel akan semakin meningkat mengikuti rating bintang yang dimiliki. Semakin tinggi rating maka semakin tinggi tuntutan akan pemenuhan kualitas dan fasilitas dari jasa yang disediakan bagi pelanggan. Setiap tingkatan rating bintang memiliki persyaratan kualifikasi fasilitas yang harus dipenuhi.

\footnotetext{
${ }^{2}$ Wawancara dilakukan 17 Juni 2016, informan ini telah bergabung pada hotel ini tidak kurang dari 10 tahun ${ }^{3}$ Wawancara dilakukan 28 Juni 2016, informan tersebut baru mendapatkan promosi menjadi financial controller setelah seblumnya menjabat sebagi chief accounting, bergabung pada hotel in lebih dari 12 tahun

${ }^{4}$ Wawancara dilakukan 7 Juli 2016, informan tersebut sudah lebih 20 tahun terlibat dalam pengelolaan hotel dan pernah bergabung dalam pengelolaan di lebih dari 5 hotel berjaringan
} 
Kualitas dari fasilitas akan selalu berkaitan dengan nilai investasi dan nilai cost yang harus diperhitung. Operasional yang efektif harus didukung oleh perhitungan yang cermat. Perhitungan yang cermat harus didukung oleh informasi yang handal. Pada situasi ini, fungsi akuntansi dituntut memiliki peran yang lebih besar dalam pengabilan keputusan strategis. Kehandalan dalam menentukan target cost dan target revenue akan sangat ditentukan oleh seberapa canggih sistem dan alat akuntansi yang dipakai. Oleh karena itu menjadi beralasan jika pilihan operasi hotel pada tingkat rating bintang yang semakin tinggi akan berdampak pada tuntutan implementasi peran akuntansi manajemen strategik yang lebih handal. Hal ini juga menkonfirmasi temuan Lamminmaki (2008) rating sebuah hotel akan mempengaruhi peran kecangihan akuntansi yang diimplementasikan.

Temuan penelitian ini juga semakin menjelaskan bahwa operasi bisnis hotel sangat membutuhkan peran dari fungsi akuntansi. Hal ini setidaknya teridentifikasi dari wawancara yang dilakukan terhadap Cheif Accounting Hotel Bintang 3 jaringan nasional yang menyatakan;

......fungsi akuntansi baik sebagai manusia maupun alat sangat penting dalam mengelola informasi sebagai dasar pengambilan keputusan strategis, semua proses kegitan bisnis hotel dimulai dari kegiatan akuntansi, ketepatan keputusan sangat bergantung pada informasi yang diberikan fungsi akuntansi, fungsi akuntansi akan menjadi unsur penting dalam menciptakan kinerja optimal hotel......

Penyataan tersebut menggambarkan bahwa akuntansi tidak lagi menjadi fungsi teknis, namun akuntansi sudah menjadi fungsi yang sangat strategis. Akuntansi mempunyai peran yang sangat strategis dalam pengelolaan hotel. Fungsi akuntansi baik sebagai manusia (personil akuntansi) mauapun teknologi canggih akuntansi sangat diperlukan perannya dalam menghasilkan informasi yang dapat mendukung terciptanya kinerja optimal hotel. Hal ini membuktikan bahwa implementasi akuntansi manajemen strategik pada industri hotel telah menjadi kebutuhan, khusunya untuk hotel-hotel yang mempunyai rating bntang tinggi. Hal ini juga mengkonfirmasi Collier dan Gregory (1995) yang menyatakan bahwa fungsi keuangan industri hotel telah semakin terlibat dalam akuntansi manajemen strategik. Fungsi keuangan hotel telah beralih dalam praktik akuntansi manajemen strategik yang berperan dalam menentukan perencanaan dan menganalisis persaingan guna menciptakan kinerja optimal hotel.

Fasilitas yang diberikan akuntasi manajemen strategik untuk mengidentifikasi dan memenangkan persaingan bisnis antara lain adalah menawarkan teknik-teknik akuntansi manajemen strategik berupa activity based costing/management, life cycle costing, quality costing, target costing, value chain costing, coustomer accounting, competitive position monitoring, competitor cost assesment, competitor performance appraisal, benchmarking, integrated performance measurement (Cinquini dan Tenucci, 2008). Pada situasi persaingan ketat fungsional akuntansi akan sangat terbantu dalam mengidentifikasi peluang dan persaingan menggunakan teknik-teknik akuntansi manajemen strategik tersebut. Berdasarkan data yang dikumpulkan dalam penelitian ini telah membuktikan bahwa rata-rata penggunaan teknik akuntansi manajemen strategik tersebut sudah sangat tinggi khususnya pada industri hotel di Sumatera Selatan.

\footnotetext{
${ }^{5}$ Wawancara dilakukan 29 Juni 2016, informan hampir 1 tahun menjabat CA di hotel ini, sebelumnya adalah staf accounting di hotel bintang 4 berjaringan internasional
} 


\section{PENUTUP}

Simpulan. Kesimpulan yang dapat ditemukan dari penelitian ini adalah, rating bintang sebagai parameter level dan kualitas sebuah hotel membawa dampak pada tingkat implementasi akuntansi manajemen strategik pada pengelolaan hotel, khususnya di wilayah Provinsi Sumatera Selatan. Semakin tinggi rating bintang maka akan berhubungan dengan sifat dan kualitas jasa yang dijual. Semakin tinggi rating bintang maka akan semakin banyak fasilitas yang harus disediakan untuk dijual. Semakin banyak fasilitas yang dijual maka akan semakin menghadapi persaingan yang lebih kompleks. Untuk itu hotel harus didukung oleh fungsional akuntansi yang hadal, yang mampu menyediakan informasi-informasi strategis bagi manajemen guna menentukan kebijakan dan keputusan strategis bisnis. Untuk membantu fungsional akuntansi menghasilkan informasi strategis bagi manajemen, maka perlu dukungan teknik-teknik akuntansi manajemen canggih yang dikenal sebagai penggunaan akuntansi manajemen strategik. Oleh karena itu, sangat beralasan jika penelitian ini menyimpulkan bahwa semakin tinggi rating bintang akan berdampak positif dalam implementasi akuntansi manajemen strategik, baik dalam konteks peran fungsional akuntansi maupun dalam penggunaan teknik akuntansi manajemen strategik.

Saran. Penelitian ini tentunya tidak lepas dari keterbatasan. Industri hotel akan lebih ideal jika beroperasi di daerah yang berfokus pada industri pariwisata. Sumatera Selatan khusunya Palembang merupakan daerah yang belum dapat dikatagorikan sebagai kawasan wisata. Sumatera Selatan saat ini lebih dikategorikan sebagai daerah bisnis dan perdagangan, oleh sebab itu hidupnya industri hotel di tempat ini belum dapat dikatakan sebagai tempat ideal bagi tumbuhnya industri hotel. Perbedaan mendasar dari karetistik lingkungan hotel di Sumatera Selatan bisa berdampak pada tingkat persaingan dan tingkat rata-rata hunian hotel jika dibandingkan dengan hotel-hotel yang hidup dikawasan pariwisata. Untuk itu temuan dari penelitian ini tidak dapat digeneralisasi untuk semua industri hotel. Hal yang dapat disarankan untuk penelitian kedepan adalah dapat melihat konteks yang sama di wilayah yang meiliki karateristik berbeda yaitu kawasan wisata, dan bila mungkin mengkoparasi untuk keduanya.

Penelitian ini melihat peran fungsional akuntansi dalam sifat yang lebih umum dan cenderung normatif. Penelitian kedepan dapat disarankan untuk merancang instrumen peran yang lebih konkrit misalnya mengidentifikasi tingkat frekuensi fungsional akuntansi dalam menyampaikan saran atau evaluasi pengelolaan hotel, mengidentifikasi latar belakang pendidikan staf funsional akuntansi guna mengidentifikasi kompetensi staf dalam menjalankan aktifitas fungsi akuntansi. Hal-hal tersebut dimungkinkan dapat memberikan informasi yang lebih konkrit sehubungan dengan peran dan kompetensi funsional akuntansi sebuah hotel.

\section{DAFTAR RUJUKAN}

Bastian, E. and Muchlish, M. (2012) Perceived Environment Uncertainty, Business Strategy, Performance Measurement System and Organizational Performance. Procedia - Social and behavioral Sciences. Vol: 787 - 792

Bisbe, J and Malagueno, R. (2012) "Using Strategic Performance Measurement Systems for Strategy Formulation: Does it Work in Dynamic Environments?", Management Accounting Research. Vol. 23: 296 - 311 
Bromwich, M. (1996) Strategic Management Accounting in Management Accounting Handbook. Drury. C. (Ed) The Chartered Institute of Management Accountants. pp: $203-227$

Brouthers, K. D. and Roozen, F. A. (1999) "It is time to start thingking about strategic accounting?" Long Rage Planning. 32 (3), 311 - 322

Cadez, S. and Guilding, C. (2008) "An Exploratory Investigation of an Integrated Contigency Model of Strategy Management Accounting". Accounting Organizations and Society. Vol. 33: $836-863$

Cinquin, L. and Tennuci, A. (2010) "Strategic Management Accounting and Business Strategy: a Loose Coupling?" Journal of Accounting \& Organizational Change. Vol. 6 (2), $228-259$

Coleman, R. W. (1949) The Role of Acconting in Management.The Accounting Review. Vol. 24 (2), $179-183$

Collier, P. and Gregory, A. (1995) “Strategic Management Accounting”.International Journal of Contemporary Hospitality Management. Vol. 7 (1), 16 - 21

Claver, E. Tari, J. J. and Pereira, J. (2006) “Does Quality Impact on Hotel Performance?". International Journal of Contemporary Hospitality Management. Vol. 18 (4), 350 358

Cleary, P. (2015) “An Empirical Investigation of the Impact of Management Accounting on Structural Capital and Business Performance". Journal of Intellectual Capital. Vol. 16 (3), 566 - 586

Cravens, K. S. and Guilding, C. (2001) "An Empirical Study of the Application of Strategic Management Accounting Techniques". Advances in Management Accounting. 10, $95-124$

Fleming, D. M. Chow, W. C. and Chen, G. (2009) "Strategy, Performance Measurement Systems, and Performance: A Study of Chinese Firms". The International Journal of Accounting. 44, $256-278$

Ghozali, I. (2013) Aplikasi Analisis Multivariat dengan Program SPSS. Semarang Badan Penerbit Universitas Diponegoro.

Gil, D. N. (2004) "The Role of Sophisticated Accounting System in Strategy Management". The International Journal of Digital Accounting Research. 4(8), 125 144

Guilding, C. Cravens, K.S. and Tayles, M. (2000) "An international comparison of strategic management accounting practices". Management Accounting Research. 11 (1), 113-135.

Guilding, C. and McManus L. (2002) "The Incidence, Perceived Merit and Antecedents of Customer Accounting: An Exploratory Note". Accounting Organizations and Society. $27,45-59$

Hoque, Z. (2004) "A Contingency Model of the Association Berween Strategy, Environmental Uncertainty and Performance Measurement: Impact on Organizational Performance". International Business Review. 13, 485 - 502

Hyvonen, J. (2007) "Strategy Performance Measurement Technique and Information Technology of the Firm and Their Links to Organizational Performance". Management Accounting Research. 18, 343 - 366

Kim, W. G. Cho, M. and Brymer, R. A. (2013) "Determinants affecting comprehensive property-level hotel performance: The moderating role of hotel type". International Journal of Hospitality Management. 34, 404- 412 
Lamminmaki, D. (2008) "Accounting and the Management of Outsourcing: An Emperical Study in the Hotel Industry". Management Accounting Research. 19, 163 - 181

Lee, C. L. and Yang, H. J. (2011) "Organization Structure, Competition and Performance Measurement System and Their Joint Effect on Performance". Management Accounting Research. 22, 84 - 104

Macinati, M. S. and Pessina, E. A. (2014) "Management Accounting Use and Fianancial Performane in Public Health-Care Organisations: Evidencw from the Italian National Health Service". Health Policy, 117, 98 - 111

Nixon, B. and Burns, J. (2012) "The paradox of strategic management accounting". Management Accounting Research. 23, 229 - 244

Rhee, H. T. and Yang, S. B. (2015) Does hotel attribute importance differ by hotel? Focusing on hotel star-classifications and customers' overall ratings. Computers in Human Behavior. 50, 576 - 587

Tari, J. J. Cortes, E. C. Jorge. Jose, P. M. and Azorin, F. M. (2009) "Is it worthwhile to be a quality certified hotel? Evidence from Spain". International Journal of Quality \& Reliability Management. 26 (9), 850 - 864

Teeratansirikool, L. Siengthai, S. Badir, Y. and Charoenngam, C. (2013) "Competitive Strategies and Firms Performance: The Mediating Role of Performance measurement". International Journal of Productvity and Performance Management. Vol. 62 (2), $168-184$

Wooldridge, B. and Floyd, S. W. (1990) "The Strategy Process, Middle Management Involvement and Organizational Performance". Strategic Management Journal. 11, $231-241$

http://agoda.com

http://traveloka.com

http://hotelcombined.com 